
УДК 616-083.98:614.23/.25:614.252.2:378.2

DOI 10.11603/1811-2471.2019.v.i4.10798

\title{
АКТУАЛЬНІСТЬ СИМУЛЯЦІЙНИХ МЕТОДІВ НАВЧАННЯ НА ЕТАПІ ПІСЛЯДИПЛОМНОї ОСВІТИ ВИПУСКНИКІВ ВИЩИХ МЕДИЧНИХ НАВЧАЛЬНИХ ЗАКЛАДІВ
}

\author{
ФН. В. Малютіна', С. І. Бабак², Л. В. Клименко ${ }^{1}$, О. І. Погоріла' \\ ${ }^{1}$ Національна медична академія післядипломної освіти імені П. Л. Шупика, \\ ${ }^{2}$ Київська обласна клінічна лікарня
}

РЕЗЮМЕ. Згідно із сучасними світовими тенденціями та запитом вітчизняної медицини, найдоцільнішим способом оволодіння практичними навичками як студентами, починаючи з першого курсу, так і лікарями-практиками, є тренінги у симуляційних центрах.

Мета - визначення рівня компетентності випускників вищих медичних навчальних закладів щодо володіння переліком практичних навичок та умінь.

Матеріал і методи. Проведено анкетування за шкалою оцінки знань Королівського коледжу лікарів загальної практики у двох групах лікарів-інтернів першого року навчання зі спеціальності «Загальна практика - сімейна медицина" до та після практичного заняття у симуляційному центрі. До 1 групи увійшли лікарі-інтерни, які під час отримання освіти не мали практичного медичного досвіду за межами вищого навчального закладу (n=86); до 2 групи (n=16) - лікарі-інтерни, які під час навчання працювали у закладах охорони здоров'я на посадах середніх медичних працівників.

Результати. У результаті аналізу отриманих даних було встановлено, що лікарі-інтерни 1 групи оцінили свій рівень володіння практичними навичками, як такий, що потребує підвищення. Лікарі-інтерни, які під час отримання освіти у медичних вищих навчальних закладах працювали у закладах охорони здоров'я, мали достовірно вищий рівень показників володіння практичними навичками, що належать до компетенції середнього медичного персоналу.

Висновки. Тренінги щодо рівня оволодіння практичними навичками та уміннями при застосуванні симуляційних методів навчання $є$ високоефективними, що доводять результати наших досліджень.

КЛЮчОВІ СЛОВА: симуляційні методи навчання; післядипломна освіта; практичні навички.

Вступ. Згідно із Конституцією України, всі медичні працівники зобов'язані безоплатно надавати першу невідкладну медичну допомогу громадянам при нещасних випадках, гострих захворюваннях та інших екстремальних ситуаціях [1], що вимагає від фахівця достатнього рівня обізнаності щодо клініки, діагностики та принципів надання медичної допомоги в таких ситуаціях [2]. Невід'ємною складовою надання якісної, а отже ефективної та безпечної невідкладної медичної допомоги, $\epsilon$ досконале володіння цілою низкою медичних маніпуляцій.

Найпоширенішим способом набуття та відпрацювання практичних навичок (в тому числі і з невідкладної допомоги) вітчизняними медичними працівниками дотепер залишається навчання «біля ліжка пацієнта». Цей метод звичайно характеризується цілим рядом безперечних переваг: досвід взаємодії з різними пацієнтами, можливість спостерігати за діями професіоналів, розвиток клінічного мислення, підготовка до самостійної діяльності та інше.

Однак якісне та безпечне оволодіння практичними навичками "біля ліжка пацієнта», особливо навичками з надання невідкладної допомоги, $\epsilon$ надзвичайно складним завданням [3]. Формування будь-якої навички забезпечується шляхом бага- торазових повторень, доведенням до автоматизму здатності виконувати конкретну дію. На базі сформованої навички ґрунтується вміння - відпрацьований фахівцем спосіб виконання складних дій, що забезпечується сукупністю знань і навичок [4].

Необхідно зазначити, що навіть при засвоєнні клінічних дисциплін терапевтичного профілю оволодіння практичними навичками способом «біля ліжка пацієнта» не позбавлене певних недоліків. Далеко не завжди $\epsilon$ можливість здійснити повноцінне клінічне обговорення, ретельне обстеження тематичних хворих, якісне відпрацювання маніпуляцій та забезпечити адекватний контроль викладача за якістю виконання завдання та ступенем досягнення компетентності (виконання дій з їх обґрунтуванням) кожним слухачем. Крім того, ситуація додатково ускладнюється відсутністю можливості забезпечити кожного слухача «тематичним хворим» [5], а також гарантованої можливості самостійно виконати певну маніпуляцію.

Разом із тим, якщо при курації планових пацієнтів терапевтичного профілю зберігається часткова можливість оволодіння практичними навичками та уміннями шляхом багаторазового повторення дій, наприклад, аускультація легень, серця, електрокардіографія, пальпація живота та інше, то специфіка оволодіння навичками з невідклад- 
Огляди літератури, оригінальні дослідження, погляд на проблему, випадок з практики, короткі повідомлення них станів обумовлює майже повне виключення не тільки багаторазового відтворення маніпуляцій, а й здебільшого унеможливлює демонстрацію клінічного випадку (наприклад, конікотомія, прийом Геймліха, заходи серцево-легеневої та церебральної реанімації) [3]. Крім того, процес навчання «біля ліжка пацієнта» характеризується великою ймовірністю помилки, а також пов'язаний із порушенням права пацієнта на якісне надання медичної допомоги та інше.

Тому, в теперішніх умовах зростання вимог до державних освітніх стандартів щодо професійних компетенцій медичних фахівців та з урахуванням сучасних світових тенденцій, єдиним шляхом вирішення визначених проблем може бути створення симуляційних центрів для підготовки як студентів, починаючи з першого курсу, так і лікарів-практиків [3, 5]. Оволодіння практичними навичками з використанням симуляційних методів навчання характеризується низкою безперечних переваг, порівняно із традиційними методами навчання «біля ліжка пацієнта»: набуття клінічного досвіду у віртуальному середовищі без ризику для життя та здоров'я пацієнта; реалізація індивідуального підходу до навчання; висока засвоюваність матеріалу за короткий проміжок часу; мож-

ливість простежити динаміку когнітивного зростання; можливість об'єктивно оцінити досягнутий рівень майстерності; необмежена кількість повторів відпрацювання навички; можливість організації тренінгу в зручний час, незалежно від роботи клініки; відпрацювання дій при рідкісних та загрозливих для життя патологіях; знижений рівень стресу при перших самостійних маніпуляціях; можливість навчання керуванню ризиками при наданні невідкладної медичної допомоги $[3,4]$.

Мета - визначення рівня компетентності випускників вищих медичних навчальних закладів щодо володіння практичними навичками та уміннями.

Матеріал і методи дослідження. Для вирішення поставлених задач на базі кафедри сімейної медицини та амбулаторно-поліклінічної допомоги Національної медичної академії післядипломної освіти імені П. Л. Шупика було проведено анкетування випускників вищих медичних навчальних закладів на етапі післядипломної освіти, а саме лікарів-інтернів зі спеціальності «Загальна практика - сімейна медицина», щодо володіння практичними навичками та уміннями за шкалою оцінки знань Королівського коледжу лікарів загальної практики (табл. 1).

Таблиця 1. Шкала оцінки знань Королівського коледжу сімейних лікарів (Лондон, 2008)

\begin{tabular}{|l|c|}
\hline \multicolumn{1}{|c|}{ Рівень знань } & Оцінка в балах \\
\hline Не впевнений(на) & 1 \\
\hline Маю деякі знання чи вміння у цій сфері, але не вважаю себе компетентним(ою) & 2 \\
\hline Вважаю себе компетентним(ою), але бажаю покращити рівень знань у цій сфері & 3 \\
\hline Впевнений(на), мої знання є достатніми & 4 \\
\hline Абсолютно упевнений(на) у цій сфері знань & 5 \\
\hline
\end{tabular}

Респондентам було запропоновано анонімно заповнити анкети з метою самооцінки володіння переліком практичних навичок, щодо яких повинен бути висококомпетентним кожен медичний працівник і які часто використовуються при наданні невідкладної допомоги. До цього переліку увійшли наступні маніпуляції:

- забір крові з вени з використанням одноразового шприца;

- внутрішньовенна ін'єкція з використанням одноразового шприца;

- катетеризація периферійної вени периферійним внутрішньовенним катетером (ПВВК);

- налагодження внутрішньовенної інфузії;

• проведення штучної вентиляції легень (ШВЛ)

способом «з рота в рот» у дорослих;

- проведення непрямого масажу серця (HMC) у дорослих;

- прийом Геймліха;

- потрійний прийом за П. Сафаром у дорослих;
• надання пацієнту стабільного положення на боці.

Анкетування з метою визначення самооцінки рівня володіння переліком практичних навичок було проведено у двох групах лікарів-інтернів першого року навчання до та після практичного заняття у симуляційному центрі Інституту сімейної медицини НМАПО імені П. Л. Шупика. До 1 групи (n=86) увійшли лікарі-інтерни, які не мали практичного медичного досвіду за межами вищого навчального закладу. 2-у групу $(n=16)$ склали лікарі-інтерни, які під час отримання освіти у ВНЗ працювали в закладах охорони здоров'я на посадах середніх медичних працівників (палатна, маніпуляційна медична сестра тощо).

Результати й обговорення. В результаті проведеного анкетування було визначено початкову самооцінку лікарями-інтернами рівня володіння переліком практичних навичок (рис. 1). 
Огляди літератури, оригінальні дослідження, погляд на проблему, випадок з практики, короткі повідомлення

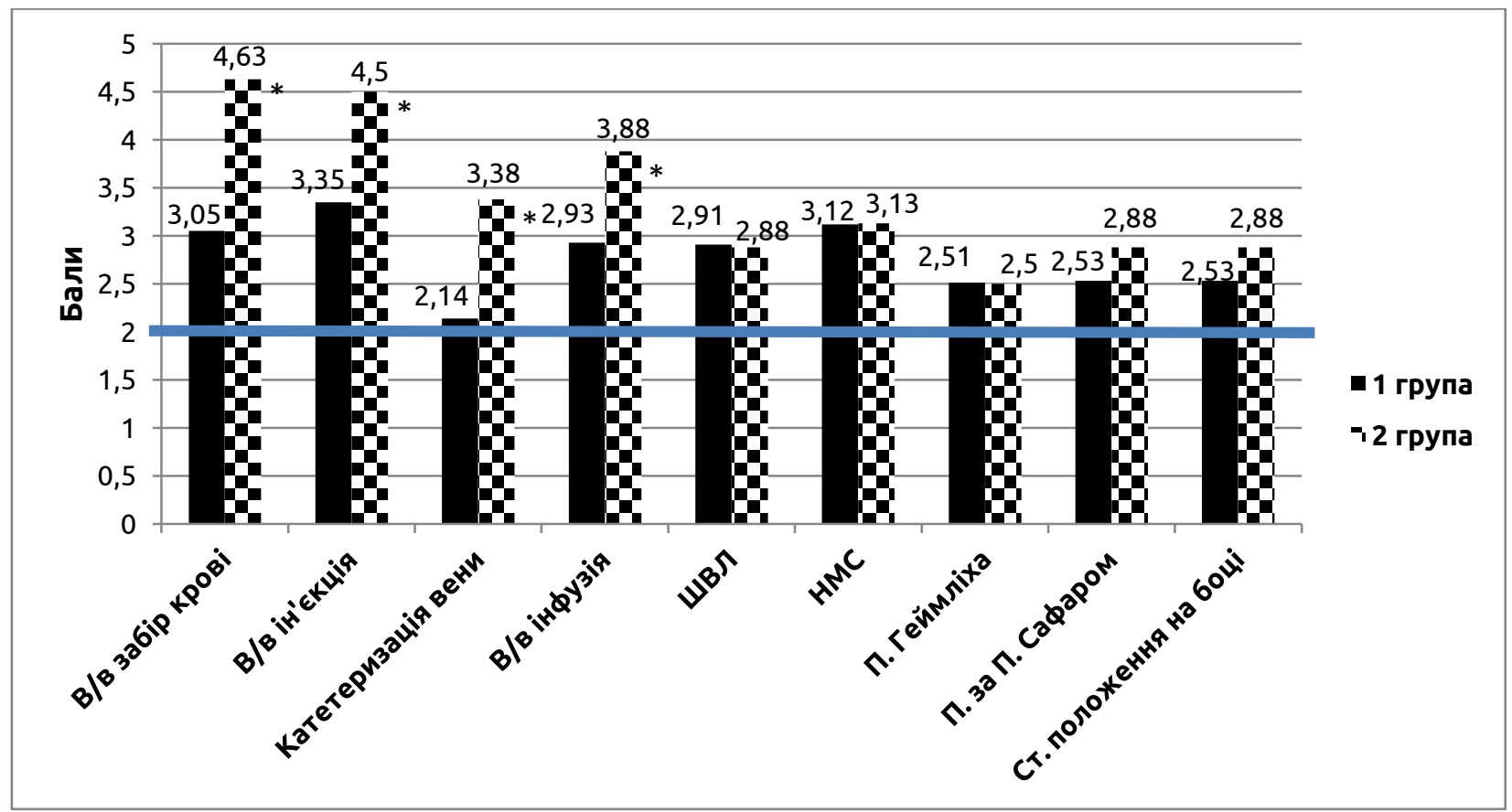

Примітка. * - p<0,05. 2 груп.

Рис. 1 Порівняння початкової бальної самооцінки володіння практичним навичками лікарів-інтернів 1 та

Згідно з отриманими даними, лікарі-інтерни 1 групи оцінили свій рівень знань щодо виконання усіх перелічених маніпуляцій до заняття у тренінговому центрі як такий, що потребує підвищення. Найнижчу загальну бальну оцінку отримали маніпуляції, що не досягали рівня компетенції (оцінка становила <3 балів), а саме:

- катетеризація периферійної вени ПВВК;

- налагодження внутрішньовенної інфузії;

- проведення ШВЛ способом «з рота в рот» у дорослих;

- прийом Геймліха;

- потрійний прийом за П. Сафаром у дорослих;

- надання пацієнту стабільного положення на боці.

При цьому рівень некомпетентності (самооцінка рівня володіння навичками $\leq 2$ балів) від- повідав наступним показникам (табл. 2): 69,77 \% опитуваних визнали себе некомпетентними щодо катетеризації периферійної вени ПВВК, щодо виконання прийому Геймліха, прийому за П. Сафаром та розміщення пацієнта у стабільному положенні на боці - 55,81\%; 46,51 \% та 53,49 \% респондентів відповідно. 32,56 \% опитаних лікарів-інтернів визнали неспроможність виконати забір венозної крові з використанням одноразового шприца та налагодити внутрішньовенну інфузію, а 30,23 \% не впевнені у своїх знаннях щодо проведення ШВЛ у дорослих. Частка молодих спеціалістів, некомпетентних щодо здійснення внутрішньовенної ін'єкції з використанням одноразового шприца та проведення НМС у дорослих, була найнижчою і становила $20,93 \%$.

Таблиця 2. Рівень некомпетентності інтернів 1 та 2 груп при початковій самооцінці рівня володіння практичними навичками

\begin{tabular}{|c|c|c|c|c|c|c|c|c|c|}
\hline \multirow[t]{2}{*}{ Група } & 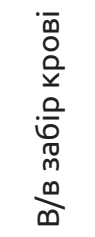 & 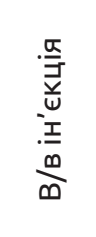 & 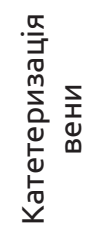 & 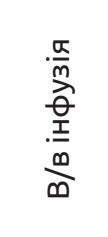 & 响 & $\sum_{I}^{\cup}$ & 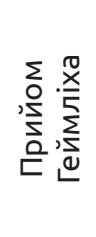 & 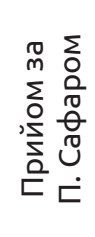 & 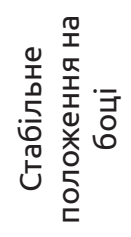 \\
\hline & \multicolumn{9}{|c|}{ Рівень некомпетентності (\%) } \\
\hline 1 група & 32,56 & 20,93 & 69,77 & 32,56 & 30,23 & 20,93 & 55,81 & 46,51 & 53,49 \\
\hline 2 група & 0 & 0 & 12,50 & 0,00 & 25,00 & 25,00 & 62,50 & 25,00 & 37,50 \\
\hline
\end{tabular}


Огляди літератури, оригінальні дослідження, погляд на проблему, випадок з практики, короткі повідомлення

Інтерни 2 групи до проходження тренінгу оцінили свої знання як достатні щодо забору венозної крові та внутрішньовенної ін'єкції з використанням одноразового шприца. Відносно таких маніпуляцій як катетеризація периферійної вени ПВВК, налагодження внутрішньовенної інфузії та проведення НMС у дорослих, респонденти вважають себе компетентними, але бажають покращити рівень знань. Найнижчу загальну оцінку по групі отримали маніпуляції, що не досягали рівня компетенції (оцінка становила <3 балів), а саме:

- проведення ШВЛ способом «з рота в рот» у дорослих;

- прийом Геймліха;

- потрійний прийом за П. Сафаром у дорослих;

- надання пацієнту стабільного положення на боці.

При цьому показники рівня некомпетентності (самооцінка рівня володіння навичками $\leq 2$ балів) дещо відрізнялись від результатів анкетування 1 групи. Усі респонденти 2 групи вважають себе компетентними щодо забору венозної крові та внутрішньовенної ін'єкції з використанням одноразового шприца, а також проведення внутрішньовенної інфузії. 62,50 \% опитуваних визнали себе некомпетентними у виконанні прийому Геймліха, $37,50 \%$ - щодо надання пацієнту стабільного положення на боці. 25,00 \% інтернів 2 групи визнали недостатній рівень знані та умінь для проведення ШВЛ способом «з рота в рот», НМС та потрійного прийому за П. Сафаром у дорослих. 12,50 \% опиту- ваних недостатньо обізнані щодо катетеризації периферійної вени ПВВК.

При порівнянні початкової бальної самооцінки володіння практичними навичками лікарів-інтернів 1 та 2 груп (рис. 1) було визначено, що опитувані 2 групи мали достовірно вищий рівень показників щодо виконання ряду маніпуляцій, які належать до компетенції середнього медичного персоналу: забір венозної крові та внутрішньовенна ін'єкція з використанням одноразового шприца (на 34,13\% та 25,56 \% відповідно), катетеризація периферійної вени ПВВК (на $36,69 \%$ ) та налагодження внутрішньовенної інфузії (на 24,49 \%). Самооцінка рівня володіння рештою практичних навичок достовірно не відрізнялася в обох групах.

Після проведення практичного заняття у тренінговому центрі з відпрацюванням перелічених практичних навичок було проведене повторне анкетування інтернів 1 групи (рис. 2). Під час проведення тренінгу було передбачено теоретичну підготовку учасників до відпрацювання практичних навичок, кількість повторів для кожного слухача була необмеженою.

За результатами повторного анкетування було визначено, що після проходження тренінгу респонденти оцінили рівень володіння практичними навичками як достовірно вищий. Найбільшу позитивну динаміку мала самооцінка щодо катетеризації периферійної вени ПВВК та проведення потрійного прийому за П. Сафаром у дорослих (82,61 \% та 71,56 \% відповідно).

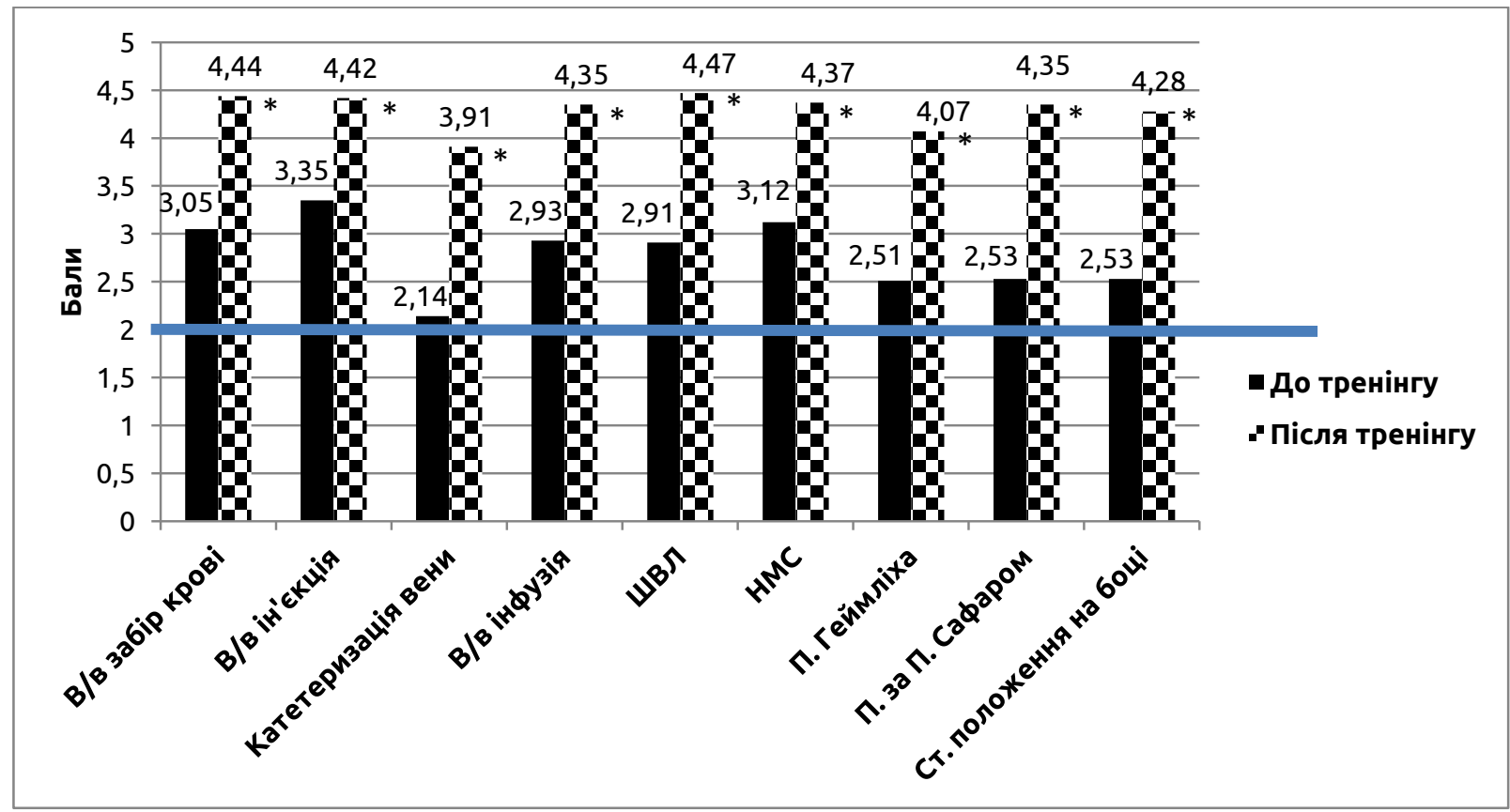

Примітка. * $-p<0,05$.

Рис. 2. Самооцінка інтернами 1 групи рівня володіння практичними навичками до та після тренінгу в симуляційному центрі. 
Огляди літератури, оригінальні дослідження, погляд на проблему, випадок з практики, короткі повідомлення

Висновки. Опитані випускники медичних ВНЗ за час навчання не набули достатнього рівня компетенції щодо володіння запропонованим переліком практичних навичок та умінь.

Лікарі-інтерни, що під час отримання освіти у ВН3 працювали у закладах охорони здоров'я, мали достовірно вищий рівень показників володіння практичними навичками, що належать до компетенції середнього медичного персоналу.

Достатній рівень компетенції щодо володіння практичними навичками та уміннями може бути забезпечений шляхом набуття практичного досвіду в тренінговому центрі.

Встановлена достатньо висока ефективність ( $\geq 30$ \%) підвищення рівня володіння практични- ми навичками та уміннями при застосуванні симуляційних методів навчання.

Наразі актуальним напрямком у сфері вищої медичної освіти має бути значне посилення практичного аспекту підготовки майбутніх лікарів при збереженні належного рівня теоретичної підготовки, оскільки тільки гармонійне поєднання глибоких теоретичних знань та повноцінного осво$\epsilon$ ння й постійного вдосконалення практичних навичок може забезпечити досягнення максимального ефекту при вивченні медичних дисциплін $[3,5,6,7]$.

Автори заявляють про відсутність конфлікту інтересів.

\section{ЛІТЕРАТУРА}

1. Права людини у сфері охорони здоров'я: практичний посібник / І. Берн, Т. Езер, Дж. Коен [та ін.] ; під наук. ред. І. Сенюти. - Львів : Вид-во ЛОБФ «Медицина і право», 2012. - 576 с.

2. Організація надання невідкладної медичної допомоги у центрі первинної медико-санітарної допомоги : методичні рекомендації / НМАПО ім. П. Л. Шупика, ДУ «Український інститут стратегічних досліджень МОЗ України», ДЗ «Дніпропетровська медична академія»; [уклад. : А. К. Толстанов, Ю. В. Вороненко, Н. Г. Гойда]. Київ. - 2012. - 14 с.

3. Роль симуляційних методів навчання на післядипломному етапі медичної освіти лікарів загальної практики - сімейних лікарів / О. Г. Шекера, Л. Ф. Матюха, H. В. Малютіна [et al.] // Збірник наукових праць співробітників НМАПО ім. П. Л. Шупика. - Випуск 23, книга 1, Київ, 2014. - С. 643-647.

4. Ковальчук Л. Я. Основні тенденції розвитку світової вищої школи. Впровадження сучасних технологій у навчальний процес Тернопільської державної медичної академії імені І. Я. Горбачевського : досягнення і перс- пективи / Л. Я. Ковальчук // Медична освіта. - 2000. № 2. - С. 5-11.

5. Левицький П. Р. Особливості засвоєння практичних навичок студентами медичного факультету з медицини надзвичайних ситуацій / П. Р. Левицький // Медична освіта. - 2012. - № 3. - С. 49-51.

6. Муравьев К. А. Симуляционное обучение в медицинском образовании - переломный момент / К. А. Муравьев, А. Б. Ходжаян, С. В. Рой // Фундаментальные исследования. - 2011. - № 10 (часть 3). - С. 534-537.

7. Гнатюк М. С. Особливості засвоєння студентами практичних навичок з оперативної хірургії та топографічної анатомії у ДВНЗ «Тернопільський державний медичний університет імені І. Я. Горбачевського» / М. С. Гнатюк, Л. В. Татарчук, О. Б. Слабий // Нові напрямки впровадження кредитно-модульної системи організації навчального процесу у вищих медичних і фармацевтичному закладах України III-IV рівнів акредитації : м-ли наук.-практ. конференції, 12-13 травня 2011 р. Тернопіль : Укрмедкнига, 2011. - С. 72-73.

\section{REFERENCES}

1. Bern, I., Ezer, T., Cohen, J., Overal, J., \& Seniuta, I. (2012). Prava liudyny u sferi okhorony zdorovia: praktychnyi posibnyk [Human rights in health: a practical guide]. Seniuta, I. (Ed.). Lviv: Vyd-vo LOBF "Medytsyna i parvo" - Lviv: Issue of LOBF "Medicine and Law" [in Ukrainian].

2. Tolstanov, A.K., Voronenko, Yu.V., \& Hoida, N.H. (2012). Orhanizatsiia nadannia nevidkladnoi medychnoi dopomohy u tsentri pervynnoi medyko-sanitarnoi dopomohy (metodychni rekomendatsii) [Organization of emergency medical care in the center of primary health care (methodical recommendations)]. NMAPO im. P.L. Shupyka, DU "Ukrainskyi instytut stratehichnykh doslidzhen MOZ Ukrainy, DZ
'Dnipropetrovska medychna akademiia” - NMAPE named by P.L. Shupyk, State Institution "Ukrainian Institute for Strategic Studies of the Ministry of Health of Ukraine", State Enterprise "Dnipropetrovsk Medical Academy". Kyiv [in Ukrainian].

3. Shekera, O.G., Matiukha, L.F., Maliutina, N.V., Klymenko, L.V., Tulika, T.I. (2014). Rol symuliatsiinykh metodiv navchannia na pisliadyplomnomu etapi medychnoi osvity likariv zahalnoi praktyky - simeinykh likariv [The role of simulation training methods in the postgraduate stage of medical education of GPs - family doctors]. Zbirnyk naukovykh prats spivrobitnykiv NMAPO im. P.L. Shupyka - Col- 
Огляди літератури, оригінальні дослідження, погляд на проблему, випадок з практики, короткі повідомлення lection of Scientific Works of NMAPE named by P.L. Shupyk, 23 (1), 643-647. Kyiv [in Ukrainian].

4. Kovalchuk, L.Ya. (2000). Osnovni tendentsii rozvytku svitovoyi vyshchoi shkoly. Vprovadzhennia suchasnykh tekhnolohii u navchalnyi protses Ternopilskoi derzhavnoi medychnoi akademii imeni I. Ya. Horbachevskoho: dosiahnennia i perspektyvy [The basic tendencies of development of the world high school. The introduction of modern technologies in the educational process of the Ternopil State Medical Academy named after I. Horbachevsky: achievements and prospects]. Medychna osvita - Medical Education, 2, 5-11 [in Ukrainian].

5. Levytskyi, P.R. (2012). Osoblyvosti zasvoiennia praktychnykh navychok studentamy medychnoho fakultetu z medytsyny nadzvychainykh sytuatsii [Features of mastering practical skills by students of the medical faculty of emergency medicine]. Medychna osvita - Medical Education, 3, 49-51 [in Ukrainian].

6. Muravyov, K.A., Khozhayan, A.B., \& Roy, S.V. (2011). Symulyatsyonnoe obuchenye $v$ medytsynskom obrazo-

vanii - perelomnyy moment [Simulation training in medical education - a turning point]. Fundamentalnye issledovaniya - Basic Research, 10 (3), 534-537 [in Russian].

7. Hnatiuk, M.S., Tatarchuk, L.V., \& Slabyi, O.B. (2011). Osoblyvosti zasvoiennia studentamy praktychnykh navychok z operatyvnoi khirurhii ta topohrafichnoi anatomii u DVNZ "Ternopilskyi derzhavnyi medychnyi universytet imeni I. Ya. Horbachevskoho" [Peculiarities of students' practical skills in surgical surgery and topographic anatomy at the Ternopil State Medical University named after I. Ya. Horbachevsky]. Novi napriamky vprovadzhennia kredytno-modulnoi systemy orhanizatsii navchalnoho protsesu u vyshchykh medychnykh i farmatsevtychnomu zakladakh Ukrainy III-IV rivniv akredytatsii: m-ly nauk.-prakt. konferentsii - New Directions of Introduction of Credit-transfer of Organization of Educational Process in Higher Medical and Pharmaceutical Establishments of Ukraine of III-IV levels of Accreditation: Materials of Conference. Ternopil: Ukrmedknyha [in Ukrainian].

\title{
АКТУАЛЬНОСТЬ СИМУЛЯЦИОННЫХ МЕТОДОВ ОБУЧЕНИЯ НА ЭТАПЕ ПОСЛЕДИПЛОМНОГО ОБРАЗОВАНИЯ ВЫПУСКНИКОВ ВЫСШИХ МЕДИЦИНСКИХ УЧЕБНЫХ ЗАВЕДЕНИЙ
}

\author{
๑Н. В. Малютина', С. И. Бабак², Л. В. Клименко', О. И. Погорелая' \\ ${ }^{1}$ Национальная медицинская академия последипломного образования имени П. Л. Шупика \\ ${ }^{2}$ Киевская областная клиническая больница
}

PEЗЮМЕ. Согласно современным мировым тенденциям и запросу отечественной медицины, целесообразным способом овладения практическими навыками как студентами, начиная с первого курса, так и врачами-практиками, являются тренинги в симуляционных центрах.

Цель - определение уровня компетентности выпускников высших медицинских учебных заведений по владению перечнем практических навыков и умений.

Материал и методы. Проведено анкетирование по шкале оценки знаний Королевского колледжа врачей общей практики в двух группах врачей-интернов первого года обучения по специальности «Общая практика семейная медицина» до и после практического занятия в симуляционном центре. В 1 группу вошли врачиинтерны, которые при получении образования не имели практического медицинского опыта за пределами высшего учебного заведения ( $n=86)$; во 2 группу $(n=16)$ - врачи-интерны, которые во время учебы работали в учреждениях здравоохранения на должностях средних медицинских работников.

Результаты. В результате анализа полученных данных было установлено, что врачи-интерны 1 группы оценили свой уровень владения практическими навыками как требующий повышения. Врачи-интерны, которые при получении образования в медицинских высших учебных заведениях работали в учреждениях здравоохранения, имели достоверно более высокий уровень показателей владения практическими навыками, относящимися к компетенции среднего медицинского персонала.

Выводы. Тренинги по уровню овладения практическими навыками и умениями при применении симуляционных методов обучения являются высокоэффективными, что доказывают результаты наших исследований.

КЛЮЧЕВЫЕ СЛОВА: симуляционные методы обучения; последипломное образование; практические навыки. 


\title{
RELEVANCY OF SIMULATION TEACHING METHODS DURING POSTGRADUATE EDUCATION OF HIGH MEDICAL INSTITUTIONS GRADUATES
}

\author{
@N. V. Malyutina', S. I. Babak', L. V. Klymenko', O. I. Pogorila' \\ ${ }^{1}$ P. Shupyk National Medical Academy of Postgraduate Education \\ ${ }^{2}$ Kyiv Regional Clinical Hospital
}

SUMMARY. According to modern world trends and the demand of domestic medicine, training in simulation centers is an appropriate way for students to learn practical skills from the first year, as well as medical practitioners.

The aim - to determine the level of competence of graduates of higher medical educational institutions in possession of a list of practical skills.

Material and Methods. A survey was conducted on the Royal College of General Practitioners knowledge assessment scale in two groups of interns of the first year of study, majoring in General Practice - Family Medicine, before and after the practical training in the simulation center. Group 1 included interns who, upon receiving education, did not have practical medical experience outside the institution of higher education $(n=86)$; group 2 ( $n=16)$ - interns who worked during their studies in healthcare institutions as paramedical workers.

Results. As a result of the analysis of the data obtained, it was found that interns of the group 1 rated their level of possession of practical skills as requiring improvement. Interns who, when receiving education in medical higher educational institutions, worked in healthcare institutions, had a significantly higher level of proficiency in practical skills related to the competence of paramedical personnel.

Conclusions. Trainings on the level of mastering of practical skills and abilities when applying simulation training methods are highly effective, which is proved by the results of our research.

KEY WORDS: simulation teaching methods; postgraduate education; practical skills. 